\title{
PEMODELAN PENGELUARAN PER KAPITA DAN PERSENTASE PENDUDUK MISKIN DI JAWA TENGAH MENGGUNAKAN REGRESI BIRESPON SPLINE TRUNCATED
}

\author{
Merinda Pangestikasari ${ }^{1}$, Rita Rahmawati ${ }^{2}$, Dwi Ispriyanti. ${ }^{3}$ \\ ${ }_{1,2,3}$ Departemen Statistika, Fakultas Sains dan Matematika, Universitas Diponegoro \\ e-mail : ritarahmawati@gmail.com
}

\begin{abstract}
The Central Bureau of Statistics states that the average per capita spending $\left(\mathrm{Y}_{1}\right)$ of Central Java Community in 2016 is around 27.808 rupiah per day. This value is still considered low, because it covers all the needs of an individual's life. The low expenditure per capita indicates the low level of welfare. Another indicator that can be used to measure community welfare is the percentage of poverty $\left(\mathrm{Y}_{2}\right)$. Through this variable can be known how proportion of people who still difficult to meet their needs. Many factors are suspected to affect welfare, one of which is the average variable of school length (X). This study aims to get the best model and know the goodness of the model. Approach is done by nonparametric regression that is regres biresponse spline truncated. Nonparametric approach is done when data function does not show certain pattern. The best spline truncated biresponse model is highly dependent on determining the order and location of the optimal knot point that has a minimum Mean Square Error (MSE) value. In this study, the best model is obtained when order of $Y_{1}$ is 2 and order of $Y_{2}$ is 2 with five knots. The location of the knot point obtained is 7,05; 7,$17 ; 7,32 ; 9,82$ and 10,29 with MSE value of 662634,2. The goodness of the model is measured based on RSquare and MAPE, R-Square $=43,21 \%$, means the variance of response variables that can be explained by the predictor variable are $43,21 \%$ while the rest is influenced by other variables and MAPE $=14,25 \%$. Based on the value of MAPE can be said that the model had a good performance.
\end{abstract}

Keywords: Welfare, Expenditure, Percentage of Povery, Birespon Spline, Truncated, MSE

\section{PENDAHULUAN}

Setiap manusia pasti memiliki pengeluaran tertentu untuk bertahan hidup perbulannya atau yang biasa disebut pengeluaran perkapita. Menurut BPS (2017b) pengeluaran perkapita perhari masyarakat Jawa Tengah masih berada dikisaran 27.808 rupiah (BPS, 2017b). Nilai ini dinilai masih rendah karena telah mencakup seluruh kebutuhan seseorang, termasuk kebutuhan sekunder. Rendahnya pengeluaran perkapita seseorang menunjukkan rendahnya kebutuhan yang mampu mereka penuhi (BPS, 2017b). Hal ini menandakan masih rendahnya kesejahteraan masyarakat tersebut. Selain pengeluaran perkapita, indikator lain yang dapat digunakan untuk mengukur kesejahteraan masyarakat adalah kemiskinan. Kemiskinan di suatu wilayah dapat dijelaskan melalui beberapa indikator salah satunya adalah persentase penduduk miskin. Melalui persentase penduduk miskin dapat diketahui berapa proporsi masyarakat yang masih kesulitan untuk memenuhi kebutuhan hidupnya (Subarna, 2012). Sehingga bisa dikatakan bahwa kesejahteraan masyarakat dapat dicerminkan oleh variabel pengeluaran perkapita dan persentase penduduk miskin, pada penelitian ini kedua variabel tersebut akan dijadikan variabel respon satu dan dua sebagai pendekatan dalam pengukuran kesejahteraan masyarakat di Jawa Tengah.

Masyarakat dapat dikatakan sejahtera apabila dapat memenuhi kebutuhan hidupnya secara mandiri.Penelitian mengenai faktor yang mempengaruhi kesejahteraan masyarakat pun telah banyak dilakukan. Qoyyimah dan Wahihi (2016) serta Pastyaningrum (2009) menggunakan faktor pendidikan sebagai variabel yang mempengaruhi kesejahteraan masyarakat. 
Analisis faktor-faktor yang mempengaruhi kesejahteraan masyarakat dapat dilakukan menggunakan analisis regresi. Terdapat dua pendekatan dalam analisis regresi yaitu regresi parametrik dan regresi nonparametrik. Pendekatan nonparametrik digunakan ketika bentuk fungsi data yang diperoleh tidak menunjukkan pola hubungan tertentu atau acak (Eubank, 1999).Regresi nonparametrik memiliki fleksibilitas yang tinggi karena bentuk estimasi kurva regresinya dapat menyesuaikan dengan data tanpa dipengaruhi oleh faktor subyektifitas peneliti. Salah satu pendekatan dalam regresi nonparametrik adalah estimator spline. Spline merupakan salah satu jenis piecewise polinomial, yaitu polinomial yang memiliki sifat tersegmen. Analisis regresi yang melibatkan dua variabel respon dan diantara variabel respon tersebut terdapat korelasi, baik secara logika maupun matematis disebut regresi birespon (Fernandes, et al., 2014).

\section{TINJAUANPUSTAKA}

\subsection{Kesejahteraan Masyarakat}

Kesejahteraan masyarakat menunjukkan ukuran keberhasilan pembangunan masyarakat dalam mencapai kehidupan yang lebih baik. Kesejahteraan memperlihatkan kondisi masyarakat berdasarkan standar kehidupan yang berlaku di lingkungannya.Masyarakat dapat dikatakan sejahtera apabila dapat memenuhi kebutuhan hidupnya secara mandiri(BPS, 2017a).

\section{a. Pengeluaran Perkapita}

Pengeluaran rata-rata perkapita adalah biaya yang dikeluarkan untuk konsumsi semua anggota rumah tangga selama sebulan baik yang berasal dari pembelian, pemberian maupun produksi sendiri dibagi dengan banyaknya anggota rumah tangga dalam rumah tangga tersebut (BPS, 2017a).

\section{b. Persentase Penduduk Miskin}

Kemiskinan merupakan ketidakmampuanseseorang untuk memenuhi kebutuhan makanan dan bukan makanan (BPS, 2017a).

\subsection{Rata-Rata Lama Sekolah}

Rata-rata lama sekolah mempunyai pengertian jumlah tahun belajar yang telah diselesaikan dalam pendidikan formal (tidak termasuk tahun yang mengulang). Penghitungan rata-rata lama sekolah yang digunakan BPS diukur dari penduduk berusia 25 tahun ke atas, karena pada usia tersebut proses belajar pada pendidikan formal diasumsikan telah berakhir (BPS, 2017a).

\subsection{Regresi Nonparametrik}

Menurut Eubank (1999) regresi nonparametrik merupakan metode pendugaan model regresi yang tidak terikat asumsi dan digunakan ketika bentuk kurva regresinya tidak diketahui. Kurva estimasi regresi nonparametrik diasumsikan mulus (smooth) dan termuat dalam suatu fungsi tertentu.Model regresi nonparametrik secara umum dapat dituliskan sebagai berikut:

$$
\begin{array}{cl}
y_{i}=f\left(x_{i}\right)+ & \varepsilon_{i}, i=1,2, \ldots, n \\
\text { dimana } y_{i} & : \text { variabel respon pengamatan ke-i } \\
x_{i} & : \text { variabel prediktor pengamatan ke-i } \\
f\left(x_{i}\right) & : \text { fungsi regresi yang tidak diketahui } \\
\varepsilon_{i} & : \text { error pengamatan ke-i }
\end{array}
$$




\subsection{Regresi Spline Truncated}

Regresi spline truncated merupakan model polinomial truncated yang memberikan fleksibilitas yang lebih baik daripada polinomial biasa.Segmen dalam Regresi Spline terbentuk berdasarkan kombinasi antara parameter pemulus orde $(m)$ dan titik knotnya $(k)$. Titik knot merupakan titik perubahan perilaku fungsi spline pada selang tertentu mengikuti pola perubahan data (Eubank, 1999). Menurut Eubank (1999), fungsi spline truncated berorde $(m)$ dengan titik-titik knot $k_{1}, k_{2} \ldots k_{r}$, dengan $r$ adalah banyaknya titik knot dapat disajikan dalam bentuk persamaan:

$$
\hat{f}(x)=\sum_{j=0}^{m-1} \hat{\beta}_{j} x^{j}+\sum_{j=1}^{r} \hat{\beta}_{j+m-1}\left(x-k_{j}\right)_{+}^{m-1}
$$

dengan fungsitruncated,

$$
\left(x_{i}-k_{j}\right)_{+}^{m-1}= \begin{cases}\left(x_{i}-k_{j}\right)^{m-1} & ; x_{i}-k_{j} \geq 0 \\ 0 & ; x_{i}-k_{j}<0\end{cases}
$$

Dalam hal ini koefisien $\hat{\beta}_{j}$ merupakan konstanta yang bernilai real dengan $j=0,1, \ldots, m+r-1$. Kemudian secara umum model splinetruncated orde ke- $m$ adalah sebagai berikut:

$$
y_{i}=\sum_{j=0}^{m-1} \beta_{j} x_{i}^{j}+\sum_{j=1}^{r} \beta_{j+m-1}\left(x_{i}-k_{j}\right)_{+}^{m-1}+\varepsilon_{i}
$$

\subsection{Regresi Nonparametrik Birespon Spline Truncated}

Menurut Fernandes,et al., (2014) analisis regresi birespon merupakan analisis yang melibatkan dua variabel respon dan di antara variabel respon tersebut terdapat korelasi atau hubungan, baik secara logika maupun matematis. Secara umum, model untuk regresi nonparametrik birespon dapat dituliskan sebagai berikut:

$$
\begin{gathered}
\hat{\boldsymbol{f}}^{(\mathbf{1})}\left(x_{i}\right)=\sum_{j=0}^{m_{1}-1} \hat{\beta}_{j}^{(1)} x_{i}^{j}+\sum_{j=1}^{r} \hat{\beta}_{j+m_{1}-1}^{(1)}\left(x_{i}-k_{j}\right)_{+}^{m_{1}-1} \\
\hat{\boldsymbol{f}}^{(2)}\left(x_{i}\right)=\sum_{j=0}^{m_{2}-1} \hat{\beta}_{j}^{(2)} x_{i}^{j}+\sum_{j=1}^{r} \hat{\beta}_{j+m_{2}-1}^{(2)}\left(x_{i}-k_{j}\right)_{+}^{m_{2}-1} \\
\text { dengan } m_{1} \quad \text { : orde untuk respon 1 } \\
m_{2} \quad \text { : orde untuk respon 2 } \\
r \quad \text { : banyak knot yang digunakan }
\end{gathered}
$$

Berikut model Regresi Birespon Spline Truncated jika disajikan dalam bentuk matriks:

$$
\mathbf{Y}=\mathbf{X} \widehat{\boldsymbol{\beta}}+\boldsymbol{\varepsilon}
$$


dimana,

$$
\mathbf{Y}=\left[\begin{array}{c}
\boldsymbol{y}_{\boldsymbol{i}}^{(\mathbf{1})} \\
-- \\
\boldsymbol{y}_{\boldsymbol{i}}^{(2)}
\end{array}\right]=\left[\begin{array}{c}
y_{1}^{(1)} \\
y_{2}^{(1)} \\
\vdots \\
y_{n}^{(1)} \\
-- \\
y_{1}^{(2)} \\
y_{2}^{(2)} \\
\vdots \\
y_{n}^{(2)}
\end{array}\right] ; \widehat{\boldsymbol{\beta}}=\left[\begin{array}{c}
\widehat{\boldsymbol{\beta}}_{\boldsymbol{i}}^{(\mathbf{1})} \\
--\overline{\beta_{i}} \\
\widehat{\boldsymbol{\beta}}_{\boldsymbol{i}}^{(2)}
\end{array}\right]=\left[\begin{array}{c}
\hat{\beta}_{0}^{(1)} \\
\hat{\beta}_{1}^{(1)} \\
\vdots \\
\hat{\beta}_{m_{1}+r-1}^{(1)} \\
-\frac{\hat{\beta}_{0}^{(2)}}{\hat{\beta}_{1}^{(2)}} \\
\vdots \\
\hat{\beta}_{m_{2}+r-1}^{(2)}
\end{array}\right] ; \boldsymbol{\varepsilon}\left[\begin{array}{c}
\varepsilon_{1}^{(1)} \\
\varepsilon_{2}^{(1)} \\
\vdots \\
\varepsilon_{n}^{(1)} \\
\varepsilon_{1}^{(2)} \\
\varepsilon_{2}^{(2)} \\
\vdots \\
\varepsilon_{n}^{(2)}
\end{array}\right] ; \mathbf{X}=\left[\begin{array}{ccc}
\boldsymbol{A} & \boldsymbol{O} \boldsymbol{A} \\
- & - \\
\boldsymbol{O} \boldsymbol{B} & \mathbf{B}
\end{array}\right]
$$

dengan,

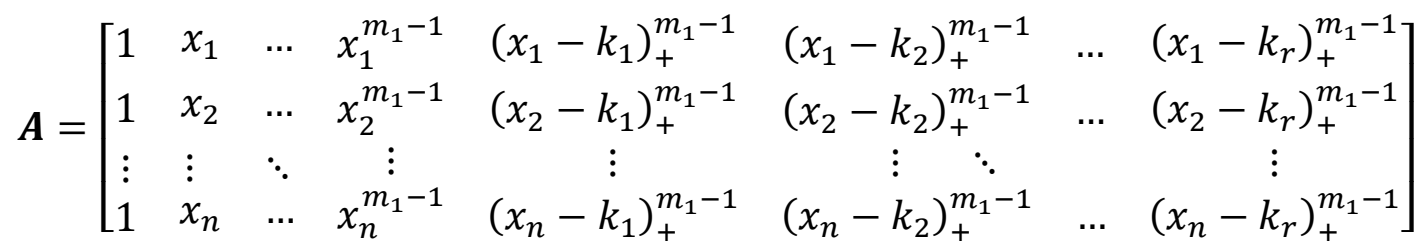

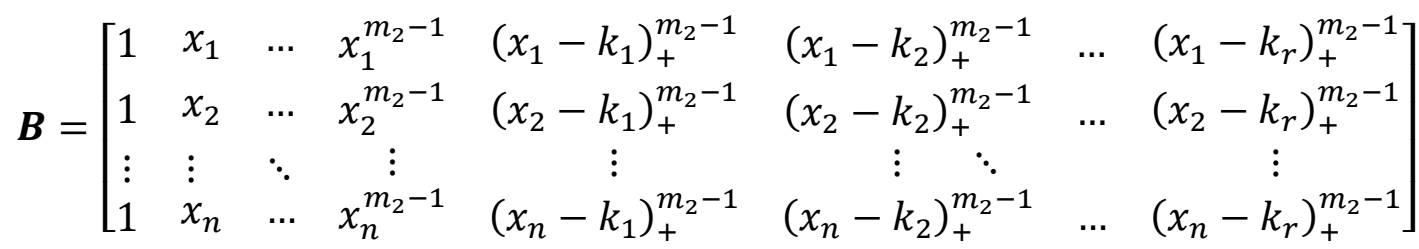

Matriks $\mathbf{Y}$ berukuran $2 \mathrm{n} \times 1$. Matriks $\widehat{\boldsymbol{\beta}}$ berukuran $(\mathrm{m} 1+\mathrm{m} 2+2 \mathrm{r}) \times 1$. Matriks $\boldsymbol{\varepsilon}$ berukuran $2 \mathrm{n} \times 1$. Matriks $\mathbf{A}$ adalah matriks berukuran $n \times\left(m_{1}+r\right)$ dan $\mathbf{B}$ adalah matriks berukuran $n \times\left(m_{2}+r\right)$. Sedangkan $\mathbf{O A}$ adalah matriks berukuran $n \times\left(m_{2}+r\right)$ yang semua elemennya bernilai nol (0) dan $\mathbf{O B}$ adalah matriks berukuran $n \times\left(m_{1}+r\right)$ yang semua elemennya bernilai nol (0). Menurut Fernandes, et al., (2014)apabila ditentukan matriks W (varian kovarian $\mathrm{Y}_{1}$ dan $\mathrm{Y}_{2}$ ) dengan ukuran $2 n \times 2 n$ adalah sebagai berikut

$$
\boldsymbol{W}=\left[\begin{array}{ccccccccc}
\sigma_{1}^{2} & 0 & \ldots & 0 & & \sigma_{12} & 0 & \ldots & 0 \\
0 & \sigma_{1}^{2} & & \vdots & \mid & 0 & \sigma_{12} & & \vdots \\
\vdots & \vdots & \ddots & 0 & & \vdots & \vdots & \ddots & 0 \\
0 & 0 & \ldots & \sigma_{1}^{2} & & 0 & 0 & \ldots & \sigma_{12} \\
- & - & - & - & \mid & - & - & - & - \\
\sigma_{12} & 0 & \ldots & 0 & & \sigma_{2}^{2} & 0 & \ldots & 0 \\
0 & \sigma_{12} & & \vdots & & 0 & \sigma_{2}^{2} & & \vdots \\
\vdots & \vdots & \ddots & 0 & \mid & \vdots & \vdots & \ddots & 0 \\
0 & 0 & \ldots & \sigma_{12} & & 0 & 0 & \ldots & \sigma_{2}^{2}
\end{array}\right]
$$

Pendugaan terhadap vektor parameter $\widehat{\boldsymbol{\beta}}$ pada persamaan 6 dilakukan dengan menggunakan metode Weighted Least Squared (WLS).

$$
\widehat{\beta}=\left(X^{T} W^{-1} X\right)^{-1} X^{T} W^{-1} Y
$$


Fungsi penduga dari $f(x)$ adalah

$$
\begin{aligned}
& \hat{f}(x)=X \widehat{\beta} \\
& \hat{f}(x)=X\left(X^{T} W^{-1} X\right)^{-1} X^{T} W^{-1} Y
\end{aligned}
$$

\subsection{Kombinasi Orde dan Titik Knot Terbaik}

Kombinasi orde dan titik knot terbaik dalam Regresi Spline Truncated dipengaruhi oleh parameter penghalus orde $(m)$, banyak titik knot dan letak dari titik knot tersebut. Semakin tinggi orde $(m)$ maka akan menghasilkan plot yang semakin mulus, dan banyak titik knot serta letaknya mengikuti karakteristik dari data. Maka sangat penting untuk mendapatkan kombinasi orde $(m)$ dan titik knot yang paling optimum.Ada beberapa metode untuk menentukan model terbaik, salah satunya dengan meminimumkan nilaiMean Square Error (MSE) (Hardle, 1994). MSE dapat dihitung dengan rumus:

$$
\begin{array}{cl}
M S E=\frac{1}{n} \sum_{i=1}^{n}\left(y_{i}-\hat{f}\left(x_{i}\right)\right)^{2} \\
\text { Dengan: } y_{i} \quad: \text { Nilai Aktual Data } \\
\hat{f}\left(x_{i}\right) & : \text { Nilai Prediksi Data dari Model } \\
n & : \text { Banyak data }
\end{array}
$$

\subsection{Uji Korelasi Spearman}

Menurut Supranto (1988), uji Korelasi dilakukan untuk mengetahui ada tidaknya hubungan antara dua variabel. Koefisien Korelasi Spearman dapat dihitung menggunakan rumus berikut:

$$
r_{s}=1-\left(\frac{6 \sum_{i=1}^{n} D_{i}^{2}}{n\left(n^{2}-1\right)}\right)
$$

dengan : $n$ : banyak data

$D_{i}$ : perbedaan peringkat pasangan pada data ke-i

Nilai $r$ selalu berada diantara -1 sampai $1(-1 \leq r \leq 1)$. Apabila nilair=-1 maka disebut dengan korelasi negatif sempurna, begitu pula sebaliknya. Apabila nilai $r=0$ menunjukkan bahwa tidak terdapat korelasi di antara kedua variabel tersebut. Uji Korelasi Spearman dilakukan dengan hipotesis:

$$
\begin{aligned}
& H_{0}: r_{s}=0 \text { (kedua variabel tidak memiliki korelasi) } \\
& H_{0}: r_{s} \neq 0 \text { (kedua variabel memiliki korelasi) }
\end{aligned}
$$

Jika ukuran data lebih besar dari 10, dapat dilakukan pengujian hipotesis dengan menghitung rasio kritis (critical ratio $=C R$ ) sebagai berikut:

$$
C R=r_{s} \sqrt{\frac{n-2}{1-r_{s}^{2}}}
$$

$n$ merupakan banyaknya pasangan data dari variabel-variabel yang diduga berkorelasi. Selanjutnya bandingkan nilai statistik uji $C R$ dengan nilai dari tabel t dengan menggunakan derajat kebebasan $n$-2. Apabila nilai $|C R|$ kurang dari $\mathrm{t}_{\text {tabel }}$ maka $\mathrm{H}_{0}$ diterima sehingga dapatdisimpulkan bahwa tidak terdapat korelasi diantara kedua variabel, demikian pula sebaliknya.

\subsection{Ukuran Kebaikan Model}

Terdapat beberapa kriteria untuk mengetahui ukuran kebaikan model, di antaranya adalah koefisien determinasi $\left(R_{\text {square }}\right)$ dan Mean Average Percentage Error (MAPE). $R_{\text {square }}$ merupakan besaran yang digunakan untuk mengukur seberapa besar variabel prediktor 
dapat menjelaskan keragaman variabel respon. Nilai dari $R_{\text {square }}$ berada pada kisaran $0 \leq r^{2}$ $\leq 1$ (Gujarati, 2003).

Koefisien determinasi dapat dihitung menggunakan rumus:

$$
\begin{aligned}
& r^{2}=\frac{\sum_{i=1}^{n}\left(\widehat{y}_{l}-\bar{y}\right)^{2}}{\sum_{i=1}^{n}\left(y_{i}-\bar{y}\right)^{2}} \\
& \text { dengan } \begin{array}{ll}
y_{i} \quad: \text { Nilai aktual } y \text { ke-i } \\
\bar{y} \quad: \text { Nilai rata-rata dari data aktual } \\
\widehat{y}_{l} \quad: \text { Nilai prediksi } y \text { ke-i }
\end{array}
\end{aligned}
$$

MAPE mengukur kesesuaian nilai dugaan model yang dinyatakan dalam bentuk ratarata persentase absolut residual. MAPE dapat dihitung menggunakan persamaan:

$$
M A P E=\frac{1}{n} \sum_{i=1}^{n}\left|\frac{\widehat{y}_{l}-y_{i}}{y_{i}}\right| \times 100 \%
$$

dimanay $_{i}=$ Data aktual pada pengamatan ke-i

$\widehat{y}_{l}=$ Data hasil prediksi pada pengamatan ke-i

$\mathrm{n}=$ banyak pengamatan yang diprediksi

Suatu model mempunyai kinerja sangat bagus jika nilai MAPE berada di bawah $10 \%$, dan mempunyai kinerja bagus jika nilai MAPE berada di antara $10 \%$ dan $20 \%$ (Myttenaera, et al.,2015).

\section{METODE PENELITIAN}

\subsection{Sumber Data dan Variabel Penelitian}

Data yang digunakan dalam penulisan tugas akhir ini merupakan data sekunder mengenai tingkat kesejahteraan rakyat yang diperoleh dari publikasi tahunan BPS Provinsi Jawa Tengah. Unit pengamatan yang digunakan adalah 35 kabupaten/kota di Provinsi Jawa Tengah pada tahun 2016. Data tersebut merupakan data cross-section.

\subsection{Variabel Penelitian}

$\mathrm{Y}_{1}$ : Pengeluaran Perkapita yang Disesuaikan (ribu rupiah/ tahun)

$\mathrm{Y}_{2}$ : Presentase Penduduk Miskin (\%)

$\mathrm{X}$ : Rata-Rata Lama Sekolah (tahun)

\subsection{Tahapan Analisis Data}

1. Memasukkan data prediktor dan data respon.

2. Melakukan Uji Korelasi Spearman untuk variabel respon $Y_{1}$ dan respon $Y_{2}$.

3. Membuat scatterplot antara variabel respon $\mathrm{Y}_{1}$ dengan variabel prediktor $\mathrm{X}$, dan variabel respon $\mathrm{Y}_{2}$ dengan variabel prediktor $\mathrm{X}$.

4. Mengkombinasikan orde antara variabel $Y_{1}$ dan $Y_{2}$.

5. Menentukan banyak dan lokasi titik knot yang akan digunakan.

6. Menghitung nilai MSE untuk setiap kombinasi orde penghalus (m) dan titik knot.

7. Menentukan kombinasi parameter penghalus orde $(\mathrm{m})$ dan banyak titik knot optimal berdasarkan nilai MSE minimum.

8. Membentuk model antara variabel respon $\mathrm{Y}_{1}$ dengan variabel prediktor $\mathrm{X}$ dan variabel respon $\mathrm{Y}_{2}$ dengan variabel prediktor $\mathrm{X}$.

9. Membandingkan dan membuat plot antara data asli dan data prediksi.

10. Menghitung nilai $R_{\text {square }}$ dan MAPE untuk mengetahui ukuran kebaikan model. 


\section{HASIL DAN PEMBAHASAN}

\subsection{Statistik Deskriptif}

Statistik Deskriptif setiap variabel yang digunakan dapat dilihat dalam tabel berikut:

Tabel 1. Statistik Deskriptif Data

\begin{tabular}{|c|r|r|r|r|}
\hline Variabel & Minimal & Maksimal & Rata-Rata & Standar Deviasi \\
\hline $\mathrm{Y}_{1}$ & 7.447 & 14.811 & $10.180,91$ & 1704,92 \\
$\mathrm{Y}_{2}$ & 4,85 & 20,53 & 12,73 & 4,15 \\
$\mathrm{X}$ & 6,05 & 10,49 & 7,45 & 1,24 \\
\hline
\end{tabular}

\subsection{Uji Korelasi Variabel Respon}

$H_{0}: r_{s}=0$ (kedua variabel respon tidak memiliki korelasi)

$H_{1}: r_{S} \neq 0$ (kedua variabel respon memiliki korelasi)

Nilai koefisien korelasi spearman $\left(r_{s}\right)$ dapat dihitung menggunakan rumus seperti pada persamaan (11):

$$
r_{s}=1-\left(\frac{6 \sum_{i=1}^{n} D_{i}}{n\left(n^{2}-1\right)}\right)=-0,522
$$

Statistik uji yang digunakan adalah critical ratio $(\mathrm{CR})=\frac{r_{s} \sqrt{n-2}}{\sqrt{1-r_{S}^{2}}}=3,407455$.

$\mathrm{H}_{0}$ ditolak apabila $C R>t_{\text {tabel. }}$. Pada penelitian ini $\mathrm{H}_{0}$ ditolak karena nilai $C R(3,407455)>t_{(1-\alpha, v)}=t_{(1-0,05 ; 33)}(1,69236)$ sehingga variabel pengeluaran perkapita dan persentase penduduk miskin berkorelasi.

\subsection{Scatterplot antara Variabel Respon dengan Variabel Prediktor}

Scatterplot dibuat untuk mengetahui pola hubungan antara dua variabel. Dalam analisis ini ingin diketahui pola hubungan antara variabel respon satu dan dua dengan variabel prediktor.Scatterplot antara variabel respon dan prediktor dapat dilihat dalam gambar berikut:

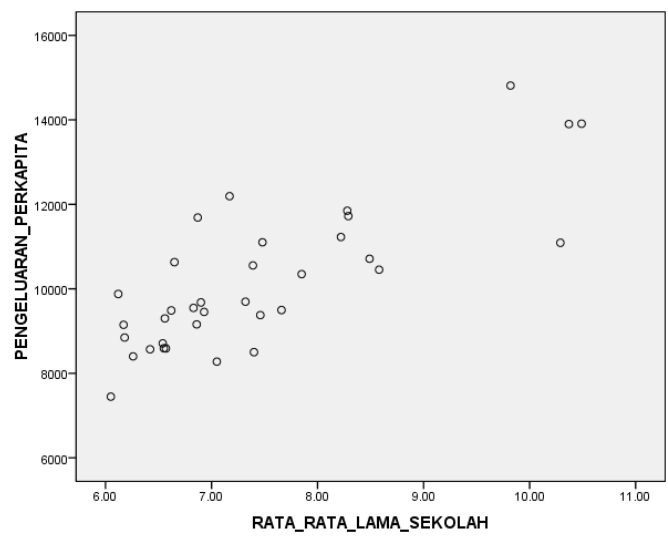

Gambar 1

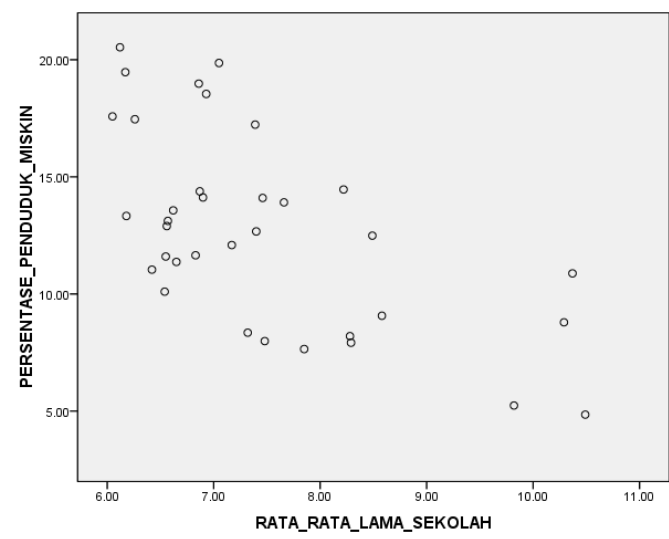

Gambar 2

Ket: Scatterplot antara variabel $\mathrm{X}$ dan $\mathrm{Y}_{1}$ (Gambar 1) dan Satterplot antara variabel X dan $\mathrm{Y}_{2}$ (Gambar 2)

Berdasarkan Gambar 1 dan Gambar 2plot antara rata-rata lama sekolah dengan variabel pengeluaran perkapita dan persentase penduduk miskin terlihat bahwa dari kedua plot di atas tidak terdapat pola hubungan tertentu atau cenderung acak. 


\subsection{Pemilihan Kombinasi Orde dan Titik Knot Optimal}

Model Birespon Spline Truncated yang optimal didapatkan dengan menentukan kombinasi orde antara variabel respon dan kombinasi letak titik knot pada variabel prediktor. Pendekatan dimulai dari orde 2 sampai orde 4 . Banyak titik knot yang akan digunakan pada variabel prediktor yaitu satu titik knot sampai lima titik knot. Pendekatan ini memungkinkan setiap variabel respon memiliki orde yang berbeda. Kemungkinan titik knot yang dicobakan pada penelitian ini adalah setiap nilai dari variabel X.

Pada penelitian ini, metode yang digunakan untuk menentukan kombinasi orde dan knot optimal adalah metode Mean Square Error (MSE). Kombinasi optimal adalah kombinasi dengan MSE minimum, yang nantinya akan menghasilkan estimasi terbaik. Dengan menggunakan software R i386 3.4.2 didapatkan hasil sebagai berikut:

Tabel 2. Nilai MSE minimum pada masing-masing jumlah knot

\begin{tabular}{|c|c|c|c|c|c|c|c|}
\hline Orde $\mathrm{Y}_{1}$ & Orde $\mathrm{Y}_{2}$ & MSE & \multicolumn{5}{|c|}{ Titik Knot } \\
\hline 2 & 3 & 970778,5 & 6,12 & & & & \\
4 & 4 & 875791,7 & 8,58 & 9,82 & & & \\
4 & 3 & 747747,6 & 9,82 & 10,29 & 10,37 & & \\
4 & 3 & 730200,6 & 6,26 & 9,82 & 10,29 & 10,37 & \\
2 & 2 & 662634,2 & 7,05 & 7,17 & 7,32 & 9,82 & 10,29 \\
\hline
\end{tabular}

Kombinasi orde dan titik knot optimal diperoleh pada saat $\mathrm{Y}_{1}$ berorde $2, \mathrm{Y}_{2}$ berorde 2, dengan lima titik knot. Letak titik knot $X$ pada titik 7,05; 7,17; 7,32; 9,82 dan 10,29 yang menghasilkan MSE sebesar 662634,2

\subsection{Model Regresi BiresponSpline Truncated yang Diperoleh}

Berdasarkan pembahasan diatas dapat dibentuk model birespon spline truncated untuk variabel $\mathrm{Y}_{1}$ berorde dua dengan lima titik knot $\mathrm{X}$ sebagai berikut:

$$
\begin{aligned}
\hat{\boldsymbol{f}}^{(\mathbf{1})}\left(x_{i}\right) & =\sum_{j=0}^{m_{1}-1} \hat{\beta}_{j}^{(1)} x_{i}^{j}+\sum_{j=1}^{r} \hat{\beta}_{j+m_{1}-1}^{(1)}\left(x_{i}-k_{j}\right)_{+}^{m_{1}-1} \\
\hat{\boldsymbol{f}}^{(\mathbf{1})}\left(x_{i}\right) & =\sum_{j=0}^{2-1} \hat{\beta}_{j}^{(1)} x_{i}^{j}+\sum_{j=1}^{5} \hat{\beta}_{j+2-1}^{(1)}\left(x_{i}-k_{j}\right)_{+}^{2-1} \\
& =\sum_{j=0}^{1} \hat{\beta}_{j}^{(1)} x_{i}^{j}+\sum_{j=1}^{5} \hat{\beta}_{j+1}^{(1)}\left(x_{i}-k_{j}\right)_{+}
\end{aligned}
$$

fungsi truncated-nya

$$
\left(x_{i}-k_{j}\right)_{+}= \begin{cases}\left(x_{i}-k_{j}\right) & ; x_{i}-k_{j} \geq 0 \\ 0 & ; x_{i}-k_{j}<0\end{cases}
$$

Persamaan model birespon spline dengan $\mathrm{Y}_{2}$ berorde dua dengan lima titik knot $\mathrm{X}$ sebagai berikut:

$$
\hat{\boldsymbol{f}}^{(2)}\left(x_{i}\right)=\sum_{j=0}^{m_{2}-1} \hat{\beta}_{j}^{(2)} x_{i}^{j}+\sum_{j=1}^{r} \hat{\beta}_{j+m_{2}-1}^{(2)}\left(x_{i}-k_{j}\right)_{+}^{m_{2}-1}
$$




$$
\begin{gathered}
\hat{\boldsymbol{f}}^{(2)}\left(x_{i}\right)=\sum_{j=0}^{2-1} \hat{\beta}_{j}^{(2)} x_{i}^{j}+\sum_{j=1}^{5} \hat{\beta}_{j+2-1}^{(2)}\left(x_{i}-k_{j}\right)_{+}^{2-1} \\
=\sum_{j=0}^{2} \hat{\beta}_{j}^{(2)} x_{i}^{j}+\sum_{j=1}^{5} \hat{\beta}_{j+1}^{(2)}\left(x_{i}-k_{j}\right)_{+}
\end{gathered}
$$

fungsi truncated-nya

$$
\left(x_{i}-k_{j}\right)_{+}= \begin{cases}\left(x_{i}-k_{j}\right) & ; x_{i}-k_{j} \geq 0 \\ 0 & ; x_{i}-k_{j}<0\end{cases}
$$

Berdasarkan running program diperoleh estimasi parameter model spline terbaik. Estimasi parameter model spline terbaik dapat dilihat pada tabel berikut:

Tabel 3. Estimasi Parameter Model Spline Terbaik

\begin{tabular}{|c|c|r|r|r|r|}
\hline Respon & Parameter & Estimasi Parameter & Respon & Parameter & Estimasi Parameter \\
\hline$Y_{1}$ & $\widehat{\beta_{0}^{(1)}}$ & 5305,324 & $\mathrm{Y}_{2}$ & $\widehat{\beta_{0}^{(2)}}$ & 43,72814 \\
\cline { 2 - 3 } & $\widehat{\beta_{1}^{(1)}}$ & 682,6222 & & $\widehat{\beta_{1}^{(2)}}$ & $-4,39894$ \\
\cline { 2 - 3 } & $\widehat{\beta_{2}^{(1)}}$ & 1235,620 & & $\widehat{\beta_{2}^{(2)}}$ & $-37,81460$ \\
\cline { 2 - 3 } & $\widehat{\beta_{3}^{(1)}}$ & $-11797,190$ & & $\widehat{\beta_{3}^{(2)}}$ & 73,43124 \\
\cline { 2 - 3 } & $\widehat{\beta_{4}^{(1)}}$ & 11763,420 & & $\widehat{\beta_{4}^{(2)}}$ & $-32,41970$ \\
\cline { 2 - 3 } & $\widehat{\beta_{5}^{(1)}}$ & $-2324,350$ & & $\widehat{\beta_{5}^{(2)}}$ & $-6,87174$ \\
\cline { 2 - 3 } & $\widehat{\beta_{6}^{(1)}}$ & $-8962,749$ & & $\widehat{\beta_{6}^{(2)}}$ & 23,68562 \\
\hline
\end{tabular}

Berdasarkan Tabel 3 estimasi parameter model terbaik birespon spline untuk variabel repson $\mathrm{Y}_{1}$ dapat ditulis sebagai berikut:

$$
\begin{aligned}
\hat{y}^{(1)}=5305,324 & +682,6222 x+1235,62(x-7,05)_{+}-11797,19(x-7,17)_{+} \\
& +11763,42(x-7,32)_{+}-2324,35(x-9,82)_{+} \\
& -8962,749(x-10,29)_{+}
\end{aligned}
$$

Persamaan model spline terbaik dengan truncated untuk respon $\mathrm{Y}_{1}$ adalah:

$$
\hat{y}^{(1)}=\left\{\begin{aligned}
5305,324+682,6222 x, & x<7,05 \\
-3405,797+1918,2422 x, & 7,05 \leq x<7,17 \\
81180,0553-9878,9478 x, & 7,17 \leq x<7,32 \\
-4928+1884,4722 x, & 7,32 \leq x<9,82 \\
17897,117-439,8778 x, & 9,82 \leq x<10,29 \\
110123,8042-9402,6070 x, & x \geq 10,29
\end{aligned}\right.
$$

Berdasarkan Tabel 3 estimasi parameter model terbaik birespon spline untuk variabel repson $\mathrm{Y}_{2}$ dapat ditulis sebagai berikut:

$$
\begin{aligned}
\hat{y}^{(2)}=43,72814-4,39894 x-37,8146(x-7,05)_{+}+73,43124(x-7,17)_{+} \\
-32,41970(x-7,32)_{+}-6,87174(x-9,82)_{+} \\
+23,68562(x-10,29)_{+}
\end{aligned}
$$

Persamaan model spline terbaik dengan truncated untuk respon Y2 adalah: 


$$
\hat{y}^{(2)}=\left\{\begin{aligned}
43,72814-4,39894 x, & x<7,05 \\
310,32107-42,21354 x, & 7,05 \leq x<7,17 \\
216,1809208+31,2177 x, & 7,17 \leq x<7,32 \\
21,1312832-1,202 x, & 7,32 \leq x<9,82 \\
88,61177-8,07374 x, & 9,82 \leq x<10,29 \\
155,1133298-15,61188 x, & x \geq 10,29
\end{aligned}\right.
$$

\subsection{Ukuran Kebaikan Model}

Pada penelitian ini kebaikan model diukur menggunakan Koefisien Determinasi $\left(R_{\text {square }}\right)$ dan Mean Average Percentage Error (MAPE). Nilai $R_{\text {square }}$ dihitung menggunakan persamaan (13) sebagai berikut:

$$
r^{2}=\frac{\sum_{i=1}^{n}\left(\widehat{y}_{l}-\overline{y_{l}}\right)^{2}}{\sum_{i=1}^{n}\left(y_{i}-\overline{y_{l}}\right)^{2}}=\frac{(9435-10180,91)^{2}+\ldots+(14,12-12,73)^{2}}{(9677-10180,91)^{2}+\ldots+(17,11-12,73)^{2}}
$$

Diperolah nilai $r^{2}=43,21 \%$. Nilai $r^{2}$ tersebut menunjukkan bahwa variabel rata-rata lama sekolah mampu menjelaskan keragaman kesejahteraan masyarakat sebesar $43,21 \%$ sedangkan 56,79\% sisanya dipengaruhi variabel lain.

MAPE mengukur kesesuaian nilai dugaan model yang dinyatakan dalam bentuk ratarata percentage absolute residual. MAPE dapat dihitung menggunakan persamaan (14) :

$$
\begin{aligned}
& M A P E=\frac{1}{n} \sum_{i=1}^{n}\left|\frac{\widehat{y}_{l}-y_{i}}{y_{i}}\right| \times 100 \% \\
&=\frac{1}{35}\left(\left|\frac{9435-9677}{9677}\right|+\ldots+\left|\frac{17,11-14,12}{14,12}\right|\right) \times 100 \% \\
&=14,25 \%
\end{aligned}
$$

dimana $\quad y_{i}=$ Data aktual pada pengamatan ke-i

$\widehat{y}_{l}=$ Data hasil prediksi pada pengamatan ke-i

$n=$ banyak pengamatan yang diprediksi

Berdasarkan nilai MAPE dapat dikatakan kinerja model dalam penelitian ini tergolong baik.

\section{KESIMPULAN}

Berdasarkan hasil dan pembahasan diperoleh kesimpulan sebagai berikut :

1. Model Birespon Spline Truncated terbaik untuk estimasi Pengeluaran Perkapita $\left(\mathrm{Y}_{1}\right)$ dan Persentase Penduduk Miskin $\left(\mathrm{Y}_{2}\right)$ di Jawa Tengah didapat pada saat $\mathrm{Y}_{1}$ berorde $2, \mathrm{Y}_{2}$ berorde 2 , dan $\mathrm{X}$ menggunakan lima titik knot yaitu pada titik 7,$05 ; 7,17 ; 7,32 ; 9,82$ dan 10,29 yang menghasilkan nilai MSE sebesar 662634,2 .

2. Persamaan model Birespon Spline Truncated terbaik untuk Pengeluaran Perkapita $\left(\mathrm{Y}_{1}\right)$ dan Persentase Penduduk Miskin $\left(\mathrm{Y}_{2}\right)$ di Jawa Tengah adalah:

$$
\begin{gathered}
y^{(1)}=5305,324+682,6222 x+1235,62(x-7,05)_{+} \\
-11797,19(x-7,17)_{+}+11763,42(x-7,32)_{+} \\
-2324,35(x-9,82)_{+}-8962,749(x-10,29)_{+} \\
y^{(2)}=43,72814-4,39894 x-37,8146(x-7,05)_{+}
\end{gathered}
$$




$$
\begin{aligned}
& +73,43124(x-7,17)_{+}-32,41970(x-7,32)_{+} \\
& -6,87174(x-9,82)_{+}+23,68562(x-10,29)_{+}
\end{aligned}
$$

3. Model yang diperoleh berdasarkan analisis pada penelitian ini memiliki nilai $R_{\text {square }} 43,21 \%$ dan MAPE $14,25 \%$.Berdasarkan nilai $R_{\text {square }}$, dapat dikatakan variabel rata-rata lama sekolah mampu menjelaskan keragaman kesejahteraan masyarakat sebesar 43,21\%. Berdasarkan nilai MAPE dapat dikatakan kinerja model baik.

\section{DAFTAR PUSTAKA}

BPS. 2015. Indeks Pembangunan Manusia 2014. BPS Pusat, Jakarta.

BPS. 2017a. Indikator Kesejahteraan Rakyat Provinsi Jawa Tengah 2016. BPS Provinsi Jawa Tengah, Semarang.

BPS. 2017b. Jawa Tengah Dalam Angka 2017. BPS Provinsi Jawa Tengah, Semarang.

Eubank, R. L. 1999. Spline Smoothing and Nonparametric Regression Second Edition.

Texas: Department of Statistics Southern Methodist Dallas University.

Fernandes, A. A. R., Budiantara, I N., Otok, B. W., Suhartono. 2014. Estimation of

Truncated Spline in Nonparametric Regression Bi-Response with Longitudinal Data. 2014 International Conference on Statistics and Mathematic (ICSM 2014).

Gujarati, D. N. 2003. Basic Econometrics Fourth Edition. McGraw-Hill, Inc. New York. Hardle, W. 1994. Applied Nonparametric Regression. Berlin: Universitas Humboldt.

Myttenaere, A. D., Golden, B., Grand, B. L., Rossi, F. 2015. Mean Absolute Error for Regression Models. Elsevier, volume 192 halaman 38-48.

Pastyaningrum, W., 2009.Analisis Faktor yang Mempengaruhi Kesejahteraan Masyarakat Kecamatan Tembarak, Kabupaten Temanggung. Semarang: Universitas Negeri Semarang.

Qoyyimah, Wahihi, M. M., 2016. Faktor-Faktor yang Mempengaruhi Kesejahteraan Keluarga di Desa Pucanglaban, Kecamatan Pucanglaban, Kabupaten Tulungagung. Jurnal Boga, volume 5 nomor 3.

Subarna, T. 2012. Analisis Kemiskinan dan Pengeluaran Non-Pangan Penduduk Jawa Barat. Jurnal Bina Praja, volume 4 nomor 4.

Supranto, J. 1988. Statistik: Teori dan Penerapan. Erlangga: Jakarta. 